\title{
Magnetic resonance imaging in patients with cardiac pacemakers: era of "MR Conditional" designs
}

\author{
Jerold S Shinbane ${ }^{1 *}$, Patrick M Colletti ${ }^{2}$ and Frank G Shellock ${ }^{2}$
}

\begin{abstract}
Advances in cardiac device technology have led to the first generation of magnetic resonance imaging (MRI) conditional devices, providing more diagnostic imaging options for patients with these devices, but also new controversies. Prior studies of pacemakers in patients undergoing MRI procedures have provided groundwork for design improvements. Factors related to magnetic field interactions and transfer of electromagnetic energy led to specific design changes. Ferromagnetic content was minimized. Reed switches were modified. Leads were redesigned to reduce induced currents/heating. Circuitry filters and shielding were implemented to impede or limit the transfer of certain unwanted electromagnetic effects. Prospective multicenter clinical trials to assess the safety and efficacy of the first generation of MR conditional cardiac pacemakers demonstrated no significant alterations in pacing parameters compared to controls. There were no reported complications through the one month visit including no arrhythmias, electrical reset, inhibition of generator output, or adverse sensations. The safe implementation of these new technologies requires an understanding of the well-defined patient and MR system conditions. Although scanning a patient with an MR conditional device following the strictly defined patient and MR system conditions appears straightforward, issues related to patients with pre-existing devices remain complex. Until MR conditional devices are the routine platform for all of these devices, there will still be challenging decisions regarding imaging patients with pre-existing devices where MRI is required to diagnose and manage a potentially life threatening or serious scenario. A range of other devices including ICDs, biventricular devices, and implantable physiologic monitors as well as guidance of medical procedures using MRI technology will require further biomedical device design changes and testing. The development and implementation of cardiac MR conditional devices will continue to require the expertise and collaboration of multiple disciplines and will need to prove safety, effectiveness, and cost effectiveness in patient care.
\end{abstract}

\section{Introduction}

In a previous JCMR paper entitled, "MRI in Patients with Pacemakers and ICDs: Defining the Issues", the authors discussed controversies related to imaging patients with cardiac pacemakers and implantable cardiac defibrillators (ICDs) which had not been specifically designed for the magnetic resonance imaging (MRI) environment [1]. Since that time, technological advances have led to the first generation of MR conditional cardiac pacemakers, allowing for greater patient

\footnotetext{
* Correspondence: shinbane@usc.edu

'Division of Cardiovascular Medicine/Cardiovascular and Thoracic Institute, Keck School of Medicine, University of Southern California, Los Angeles, CA 90033, USA

Full list of author information is available at the end of the article
}

management options as well as a new set of issues and controversies. One paradoxical effect created by this burst of medical innovation is the potential limitation of application of a technology due to the presence of another technology in the same patient. Because a significant percentage of patients with cardiac devices may potentially have indications for MRI during their lifetime [2], application of MR conditional devices is important to allowing patients access to MR scanning under well defined conditions. The engineering and implementation of these devices requires an understanding of: 1) all device/MRI interactions, 2) design issues to minimize or eliminate these interactions, and 3) patient management decision-making algorithms for their safe application. This review will discuss the development and 
implementation of MR conditional cardiac pacemakers and issues related to future design and implementation of other cardiac devices.

\section{Studies of MRI/Cardiac Pacemaker Interactions}

Previous studies have identified issues laying the groundwork for design improvements to engineer socalled MR conditional devices with the MRI environment under strict conditions for the patient, the device, and MRI parameters. The term, "MR conditional" refers to an item that has been demonstrated to pose no known hazards in a specified MR environment with specified conditions of use [3]. "Field" conditions that define the MR environment include static magnetic field strength, spatial gradient magnetic field, $\mathrm{dB} / \mathrm{dt}$ (time rate of change of the magnetic field), radio frequency (RF) fields, and specific absorption rate (SAR). Additional conditions, including specific configurations of the item (e.g., the routing of leads used for a neurostimulation system), may be required.

The medical literature from the pre-MR conditional cardiac device era arises from: 1) in vitro investigations of cardiac pacemakers and implantable cardiac defibrillators (ICDs), 2) isolated case reports, 3) retrospective series of patients with devices unintentionally or intentionally placed in the MRI environment and 4) prospective studies with defined patient and MR conditions [4-69]. Additionally, a physician initiated prospective multicenter site registry of pacemakers and ICDs using 1.5 Tesla non-thoracic scans has been initiated (The MagnaSafe Registry) [70,71]. Table 1 summarizes in vivo human data related to both pacemakers and ICDs. These data demonstrated certain adverse interactions of cardiac pacemakers and ICDs in the MRI environment and provided variable results regarding safety with prospective studies under defined conditions. These data led to controversy regarding study under well-defined conditions in cases where the use of MRI was essential to patient management versus the need for devices engineered to be MR conditional [1,72-79]. The issues raised by these data, however, were essential to prospective multicenter human studies completed [80-82], ongoing [83], and planned [84] to assess the safety and efficacy of the first generation of MR conditional cardiac pacemakers.

In a randomized, unblinded, two arm study of patients who met standard criteria for dual chamber pacing (484 enrolled, 464 with successful implant, 258 randomized to a single non-medically indicated MRI scan and 206 randomized to a control group) there were no significant changes in pacing parameters (sensing, threshold, or impedance change) compared to controls [81]. Both pacemaker-dependent and non-pacemaker dependent patients were studied, with MR scanning in the asynchronous mode $(\mathrm{n}=158)$, and no pacing $(\mathrm{n}=67)$ with a continuous stable rhythm during scanning. Although pacemaker dependence was not assessed at the time of scanning, $16 \mathrm{MR}$ scanned and 11 control patients had no underlying intrinsic ventricular rhythm at the pre-9- to 12-week assessment. There were no reported complications through the one month visit including arrhythmias, electrical reset, inhibition of generator output, or adverse sensations.

The safe implementation of new MR conditional technologies requires a detailed understanding of the MR nomenclature as it relates to specific patient and scanning conditions [3]. The American Society of Testing Materials (ASTM) designates devices as MR safe, MR conditional, and MR unsafe [85]. As an MR safe device would require nonmetallic, non-conducting materials and systems with no known hazards in all MR environments, it would be impossible to develop a pacing system with this designation. As MR conditional refers to devices which pose no known hazards when applied with specific conditions and a specific MR environment, the approval of a device requires strict definition of these conditions. Recently, the United States Food and Drug Administration (FDA) approved an MR conditional pacing system, the Revo ${ }^{\mathrm{TM}}$ MRI SureScan ${ }^{\circledR}$ Pacing System (Medtronic, Inc., Minneapolis, MN) [81]. Outside of the United States [Biotronik (Berlin, Germany), Medtronic, Inc. (Minneapolis, MN), and St. Jude Medical (St. Paul, MN), there are commercially available MR conditional cardiac pacemakers [86,87]. Importantly, each MR conditional system is composed of an MR conditional pulse generator, MR conditional leads, and MR conditional programming (Table 2). These and other manufacturers have systems in development and testing. Each system has its own individual conditions which must be adhered to. Therefore, knowledge of the individual system conditions is essential for the safe performance of MR scanning. In reference to scanner type, the currently approved field strength is 1.5 Tesla, and scanning is not approved for field strengths above or below this strength. Due to rapid advances in technology and clinical studies, the medical staff involved in this field must continually update their knowledge base related to MR conditional cardiac devices. This includes information on changes in devices and MR conditions as specified by the approving agency in the country where the device is being implanted and patient scanned.

\section{Design and Engineering Issues}

A cardiac pacemaker system is composed of leads and a pulse generator composed of connectors, circuitry, and a battery. In regard to the MRI environment, factors related to magnetic field interactions and transfer of 
Table 1 MRI in Patients with Pacemakers and ICDs

\begin{tabular}{|c|c|c|c|c|c|}
\hline Author & Device & Year & $\begin{array}{l}\text { Patient/ } \\
\text { Studies Report } \\
\text { Type }\end{array}$ & $\begin{array}{l}\text { MRI } \\
\text { Condition }\end{array}$ & Findings \\
\hline Iberer [8] & PPM & 1987 & 1/1 Case & & No adverse effect \\
\hline $\begin{array}{l}\text { Alonga } \\
{[11]}\end{array}$ & PPM & 1989 & $\begin{array}{l}1 / 1 \text { Case } \\
\text { Intentional }\end{array}$ & $\begin{array}{l}1.5 \mathrm{~T} \\
\text { Brain }\end{array}$ & No adverse effect \\
\hline Inbar [12] & PPM & 1993 & $\begin{array}{l}1 / 1 \text { Case } \\
\text { Intentional }\end{array}$ & $\begin{array}{l}1.5 \mathrm{~T} \\
\text { Brain } \\
\end{array}$ & No adverse effect \\
\hline $\begin{array}{l}\text { Gimbel } \\
\text { [15] }\end{array}$ & PPM & 1996 & $\begin{array}{l}/ 5 \\
\text { Retrospective } \\
\text { Intentional } \\
\end{array}$ & $\begin{array}{l}0.35-1.5 T \\
\text { Cardiac, Brain, } \\
\text { C-Spine }\end{array}$ & Two second pause \\
\hline $\begin{array}{l}\text { Garcia- } \\
\text { Boloa [16] }\end{array}$ & PPM & 1998 & $\begin{array}{l}1 / 2 \text { Case } \\
\text { Intentional }\end{array}$ & $\begin{array}{l}1.0 \mathrm{~T} \\
\text { Brain }\end{array}$ & No adverse effect \\
\hline $\begin{array}{l}\text { Fontaine } \\
\text { [98] }\end{array}$ & PPM & 1998 & $\begin{array}{l}1 / 1 \text { Case } \\
\text { Intentional }\end{array}$ & $\begin{array}{l}1.5 \mathrm{~T} \\
\text { Brain, C-Spine }\end{array}$ & Rapid pacing \\
\hline $\begin{array}{l}\text { Sommer } \\
\text { [143] }\end{array}$ & PPM & 1998 & $\begin{array}{l}\text { 18/18 } \\
\text { Prospective }\end{array}$ & $\begin{array}{l}0.5 \mathrm{~T} \\
\text { Brain, Cardiac, } \\
\text { Vascular }\end{array}$ & Asynchronous mode due to activation of the reed switch in all patients \\
\hline $\begin{array}{l}\text { Sommer } \\
{[18]}\end{array}$ & PPM & 2000 & $\begin{array}{l}45 / 51 \\
\text { Prospective }\end{array}$ & $\begin{array}{l}0.5 \mathrm{~T} \\
\text { Multiple }\end{array}$ & No adverse effect \\
\hline $\begin{array}{l}\text { Valhaus } \\
\text { [20] }\end{array}$ & PPM & 2001 & $\begin{array}{l}32 / 34 \\
\text { Prospective }\end{array}$ & $\begin{array}{l}0.5 T \\
\text { Multiple }\end{array}$ & Decrease in battery voltage recovered at 3 months \\
\hline Martin [29] & PPM & 2004 & $\begin{array}{l}54 / 62 \\
\text { Prospective }\end{array}$ & $\begin{array}{l}1.5 \mathrm{~T} \\
\text { Multiple }\end{array}$ & $\begin{array}{l}\text { Significant change in pacing threshold in } 9.4 \% \text { of leads, and } 1.9 \% \text { of leads } \\
\text { requiring an increase in programmed output. }\end{array}$ \\
\hline $\begin{array}{l}\text { Del Ojo } \\
{[32]}\end{array}$ & PPM & 2005 & $\begin{array}{l}13 / 13 \\
\text { Prospective }\end{array}$ & $\begin{array}{l}2.0 \mathrm{~T} \\
\text { Multiple }\end{array}$ & No adverse effect. \\
\hline $\begin{array}{l}\text { Rozner } \\
{[41]}\end{array}$ & PPM & 2005 & $\begin{array}{l}2 / 2 \text { Case } \\
\text { Intentional }\end{array}$ & $\begin{array}{l}1.5 \mathrm{~T} \\
\text { Thorax, } \\
\text { Lumbar }\end{array}$ & Transient change to ERI in 1 patient. \\
\hline $\begin{array}{l}\text { Gimbel } \\
{[33]}\end{array}$ & PPM & 2005 & $\begin{array}{l}10 / 11 \\
\text { Prospective }\end{array}$ & $\begin{array}{l}1.5 \mathrm{~T} \\
\text { Brain } \\
\text { C-Spine }\end{array}$ & Small variances in pacing threshold were seen in four patients. \\
\hline $\begin{array}{l}\text { Sommer } \\
{[50]}\end{array}$ & PPM & 2006 & $\begin{array}{l}115 / 82 \\
\text { Prospective }\end{array}$ & $\begin{array}{l}1.5 \mathrm{~T} \\
\text { Extra-thoracic }\end{array}$ & $\begin{array}{l}\text { Significant increase in pacing threshold, decreased lead impedance, and } \\
\text { decrease in battery voltage. No inhibition of pacing or arrhythmias and no } \\
\text { leads which required an increase in pacing output. }\end{array}$ \\
\hline $\begin{array}{l}\text { Heatlie } \\
{[52]}\end{array}$ & PPM & 2007 & 5/6 Prospective & 0.5 T Cardiac & $\begin{array}{l}\text { Pacing at maximum voltage at a fixed rate of } 100 \text { beats/minute in one } \\
\text { patient. }\end{array}$ \\
\hline $\begin{array}{l}\text { Anfinsen } \\
{[22]}\end{array}$ & ICD & 2002 & $\begin{array}{l}1 / 1 \text { Case } \\
\text { Inadvertent }\end{array}$ & $\begin{array}{l}0.5 \mathrm{~T} \\
\text { Brain }\end{array}$ & Inappropriate sensing, battery voltage transient change to EOL. \\
\hline Fiek [28] & $I C D$ & 2004 & $\begin{array}{l}1 / 1 \text { Case } \\
\text { Inadvert }\end{array}$ & $\begin{array}{l}0.5 \mathrm{~T} \\
\text { Brain }\end{array}$ & Unable to communicate with device. \\
\hline $\begin{array}{l}\text { Coman } \\
{[30]}\end{array}$ & ICD & 2004 & $\begin{array}{l}11 / 11 \\
\text { Prospective }\end{array}$ & $\begin{array}{l}1.5 \mathrm{~T} \\
\text { Cardiac, } \\
\text { Vascular, } \\
\text { General }\end{array}$ & $\begin{array}{l}\text { Brief asymptomatic pause in } 1 \text { patient. } \\
\text { Unable to communicate with device in } 1 \text { patient. }\end{array}$ \\
\hline $\begin{array}{l}\text { Gimbel } \\
{[34]}\end{array}$ & ICD & 2005 & 7/8 Prospective & $\begin{array}{l}1.5 \mathrm{~T} \\
\text { Brain, L-Spine }\end{array}$ & "Power on reset" electrical reset requiring reprogramming in 1 patient. \\
\hline $\begin{array}{l}\text { Roguin } \\
{[39]}\end{array}$ & ICD & 2005 & $\begin{array}{l}1 / 1 \text { Case } \\
\text { Intentional }\end{array}$ & 1.5 T Cardiac & No adverse effect. \\
\hline $\begin{array}{l}\text { Wollmann } \\
{[44]}\end{array}$ & ICD & 2005 & $\begin{array}{l}1 / 3 \text { Case } \\
\text { Intentional }\end{array}$ & $\begin{array}{l}1.5 \mathrm{~T} \\
\text { Brain }\end{array}$ & No adverse effect. \\
\hline $\begin{array}{l}\text { Naehle } \\
{[46]}\end{array}$ & ICD & 2006 & $\begin{array}{l}1 / 1 \text { Case } \\
\text { Intentional }\end{array}$ & $\begin{array}{l}1.5 \mathrm{~T} \\
\text { Brain }\end{array}$ & No adverse effect. \\
\hline $\begin{array}{l}\text { Nazarian } \\
{[47]}\end{array}$ & $\begin{array}{l}\text { PPM } 31 \\
\text { ICD } 24\end{array}$ & 2006 & $\begin{array}{l}68 / 55 \\
\text { Prospective }\end{array}$ & $1.5 \mathrm{~T}$ & No adverse effect. \\
\hline $\begin{array}{l}\text { Nemec } \\
{[48]}\end{array}$ & ICD & 2006 & $\begin{array}{l}1 / 1 \text { Case } \\
\text { Unintentional }\end{array}$ & $\begin{array}{l}\text { Not specified } \\
\text { Brain }\end{array}$ & $\begin{array}{l}\text { Noise detected as ventricular tachycardia and ventricular fibrillation, with no } \\
\text { therapy presumably due to magnetic mode activation. Asynchronous pacing } \\
\text { due to noise-reversal mode. }\end{array}$ \\
\hline
\end{tabular}


Table 1 MRI in Patients with Pacemakers and ICDs (Continued)

\begin{tabular}{|c|c|c|c|c|c|}
\hline $\begin{array}{l}\text { Sardanelli } \\
\text { [144] }\end{array}$ & PPM & 2006 & $\begin{array}{l}1 / 1 \text { Case } \\
\text { Intentional }\end{array}$ & $\begin{array}{l}1.5 \mathrm{~T} \\
\text { Breast } \\
\end{array}$ & No adverse effect. \\
\hline $\begin{array}{l}\text { Mollerus } \\
{[56]}\end{array}$ & $\begin{array}{l}\text { PPM } 32 \\
\text { ICD } 5\end{array}$ & 2008 & $\begin{array}{l}37 / 40 \\
\text { Prospective }\end{array}$ & $\begin{array}{l}1.5 \mathrm{~T} \\
\text { Truncal, non- } \\
\text { truncal }\end{array}$ & $\begin{array}{l}\text { No adverse effect. } \\
\text { No changes in cardiac troponin-I }\end{array}$ \\
\hline $\begin{array}{l}\text { Naehle } \\
\text { [57] }\end{array}$ & PPM & 2008 & $\begin{array}{l}44 / 51 \\
\text { Prospective }\end{array}$ & $\begin{array}{l}3.0 \mathrm{~T} \\
\text { Brain }\end{array}$ & $\begin{array}{l}\text { No adverse effect. } \\
\text { No changes in cardiac troponin-1 } \\
\text { (Use of transmit-receive head coil) }\end{array}$ \\
\hline $\begin{array}{l}\text { Gimbel } \\
{[59]}\end{array}$ & PPM & 2009 & $\begin{array}{l}1 / 1 \text { Case } \\
\text { Intentional }\end{array}$ & $\begin{array}{l}2.0 \mathrm{~T} \\
\text { Brain }\end{array}$ & Asystole \\
\hline $\begin{array}{l}\text { Goldsher } \\
\text { [60] }\end{array}$ & PPM & 2009 & $\begin{array}{l}1 / 1 \text { Case } \\
\text { Intentional }\end{array}$ & $\begin{array}{l}1.5 \mathrm{~T} \\
\text { Cervical }\end{array}$ & $\begin{array}{l}\text { No adverse effect. } \\
\text { Scan one day after implant } \\
\text { Pacemaker dependent }\end{array}$ \\
\hline $\begin{array}{l}\text { Mollerus } \\
{[61]}\end{array}$ & $\begin{array}{l}\text { PPM } 46 \\
\text { ICD } 6\end{array}$ & 2009 & $\begin{array}{l}52 / 59 \\
\text { Prospective }\end{array}$ & $\begin{array}{l}1.5 \text { Truncal, } \\
\text { non-truncal }\end{array}$ & MRI-related ectopy 7 pt \\
\hline $\begin{array}{l}\text { Naehle } \\
\text { [62] }\end{array}$ & PPM & 2009 & $\begin{array}{l}47 / 171 \text { Case } \\
\text { Intentional }\end{array}$ & $\begin{array}{l}1.5 \mathrm{~T} \\
\text { General }\end{array}$ & $\begin{array}{l}\text { Statistically significant but clinically irrelevant change in pacing capture } \\
\text { threshold and battery voltage. } \\
2 \text { or more serial scans. }\end{array}$ \\
\hline Pulver [64] & PPM & 2009 & $\begin{array}{l}8 / 11 \\
\text { Prospective }\end{array}$ & $\begin{array}{l}1.5 \mathrm{~T} \\
\text { Cardiac, non- } \\
\text { cardiac }\end{array}$ & $\begin{array}{l}\text { No adverse effect. } \\
\text { Congenital heart disease with } 9 \text { epicardial leads. }\end{array}$ \\
\hline Strach [67] & PPM & 2010 & $\begin{array}{l}114 / 114 \\
\text { Prospective }\end{array}$ & $\begin{array}{l}0.2 \mathrm{~T} \\
\text { General } \\
\end{array}$ & No adverse effect \\
\hline Millar [66] & PPM & 2010 & $1 / 1$ & $\begin{array}{l}1.5 \mathrm{~T} \\
\text { Brain C-spine }\end{array}$ & No adverse effects \\
\hline $\begin{array}{l}\text { Burke } \\
{[117]}\end{array}$ & $\begin{array}{l}\text { PPM } 24 \\
\text { ICD } 10 \\
\text { CRT ICD } 4\end{array}$ & 2010 & $\begin{array}{l}38 / 92 \\
\text { Prospective }\end{array}$ & $\begin{array}{l}1.5 \mathrm{~T} \\
\text { Brain, Spine, } \\
\text { Pelvis, } \\
\text { Extremity }\end{array}$ & $\begin{array}{l}\text { No adverse effects } \\
\text { No changes defibrillation threshold (ICD) }\end{array}$ \\
\hline $\begin{array}{l}\text { Buendia } \\
{[100]}\end{array}$ & $\begin{array}{l}\text { PPM } 28 \\
\text { ICD } 5\end{array}$ & 2010 & $\begin{array}{l}33 / 33 \\
\text { Prospective }\end{array}$ & $\begin{array}{l}1.5 \mathrm{~T} \\
\text { Cardiac Brain, } \\
\text { Spine, } \\
\text { Abdominal, } \\
\text { Extremity }\end{array}$ & $\begin{array}{l}\text { Temporary communication failure in two patients. } \\
\text { Sensing errors during imaging in two patients., } \\
\text { Safety signal generated in one pacemaker at the maximum magnetic } \\
\text { resonance frequency and output level. }\end{array}$ \\
\hline $\begin{array}{l}\text { Cohen } \\
\text { [70] }\end{array}$ & $\begin{array}{l}\text { PPM } 74 \\
\text { ICD } 31\end{array}$ & 2010 & $\begin{array}{l}\text { 105/105 } \\
\text { Prospective }\end{array}$ & $1.5 \mathrm{~T}$ & $\begin{array}{l}\text { No deaths, device failures, genrerator/lead replacements, loss of capture, or } \\
\text { electrical reset. } \\
\text { Decrease in battery voltage of } \geq 0.04 \mathrm{~V} \text { in } 2 \% \\
\text { Lead impedance change } \geq 50 \text { Ohms in } 3 \% \\
\text { High voltage impedance change } \geq 3 \text { Ohms in } 10 \% \\
\text { Decrease in R wave amplitude in } 2 \% \\
\text { Pacing threshold increase of } \geq 0.5 \mathrm{~V} \text { at } 0.4 \mathrm{~ms} \text { in } 1 \% \text { of leads }\end{array}$ \\
\hline $\begin{array}{l}\text { Wilkoff } \\
\text { [81] }\end{array}$ & $\begin{array}{l}\text { MR } \\
\text { ConditionalPPM }\end{array}$ & 2011 & $\begin{array}{l}226 / 226 \\
\text { Prospective }\end{array}$ & $\begin{array}{l}1.5 \mathrm{~T} \\
\text { Brain and } \\
\text { lumbar }\end{array}$ & No adverse effect \\
\hline $\begin{array}{l}\text { Quarta } \\
{[140]}\end{array}$ & $\begin{array}{l}\text { MR } \\
\text { ConditionalPPM }\end{array}$ & 2011 & 1/1 Prospective & $\begin{array}{l}1.5 \mathrm{~T} \\
\text { Brain, Cardiac }\end{array}$ & No adverse effect \\
\hline
\end{tabular}

Adapted and Updated from Shinbane et al. 2007. [1]

Case $=$ case report, $\mathrm{EOL}=$ end-of-life, ERI = elective-replacement indices; ICD-implantable cardiac defibrillator; PPM = pacemaker; $\mathrm{T}=$ Tesla,

electromagnetic energy must be taken into account with the specific design of these components.

\section{Pacemaker Design and Magnetic Force Issues}

The presence of ferromagnetic content in the strong static and gradient magnetic fields of the MR system can lead to movement and vibration of the cardiac device. These forces are directly related to the amount and shape of the ferromagnetic content, the location of this content in relation to the MR system, and the strength of the static magnetic field [88]. Although excessive magnetic field interactions can theoretically cause device movement, prospective data on both "standard" and MR conditional pacemakers at 1.5 Tesla did not demonstrate significant clinical effects $[32,57,81]$.

One pacemaker design mechanism to limit magnetic field interactions is minimization of ferromagnetic content of the generator. Reduction of ferromagnetic 
Table 2 MRI Patient and Scanner Conditions for Clinically Released MR Conditional Systems in the United States or the European Community

\begin{tabular}{|c|c|c|c|}
\hline System & $\begin{array}{l}\text { Medtronic EnRhythm MR|TM } \\
\text { SureScanTM Pacing System }\end{array}$ & $\begin{array}{l}\text { St. Jude Medica|TM MR Conditional } \\
\text { Pacing System }\end{array}$ & $\begin{array}{l}\text { Biotronik ProMRITM MR Conditional } \\
\text { Pacing System }\end{array}$ \\
\hline Approval & $\begin{array}{l}\text { United State (FDA appoval) } \\
\text { European Community (CE approval) }\end{array}$ & European Community (CE approval) & European Community (CE approval) \\
\hline Studies & $\begin{array}{l}\text { Wilcoff et al. [81] } \\
\text { Forleo et al. [82] } \\
\text { Advisa MRI Study [83]. (In process) }\end{array}$ & Accent MRI Study [145]. (In process) & \\
\hline Implant site & Left or right pectoral region & Left or right pectoral region & $\begin{array}{l}\text { Chest area. } \\
\text { Patient's height at least } 1.4 \text { meters }\end{array}$ \\
\hline $\begin{array}{l}\text { Limitations } \\
\text { related to other } \\
\text { devices/leads }\end{array}$ & $\begin{array}{l}\text { No active or abandoned medical devices, } \\
\text { leads, lead extenders or adaptors }\end{array}$ & $\begin{array}{l}\text { No abandoned cardiac hardware } \\
\text { including leads, lead extenders, or lead } \\
\text { adaptors }\end{array}$ & $\begin{array}{l}\text { No other pacemakers or ICDs, leads no } \\
\text { longer in use, lead adapters, lead } \\
\text { extension }\end{array}$ \\
\hline $\begin{array}{l}\text { Implant timing } \\
\text { prior to MRI }\end{array}$ & At least six weeks & Stable pacing capture threshold values & At least 6 weeks. \\
\hline $\begin{array}{l}\text { Acceptable lead } \\
\text { parameters for } \\
\text { MRI }\end{array}$ & $\begin{array}{l}\text { Capture thresholds of } \leq 2.0 \mathrm{~V} \text { at a pulse } \\
\text { width of } 0.4 \mathrm{~ms} \\
\text { Impedance of } \geq 200 \text { and } \leq 1500 \text { Ohms } \\
\text { No diaphragmatic pacing at } 5.0 \mathrm{~V} \text { at a } \\
\text { pulse width of } 1.0 \mathrm{~ms}\end{array}$ & $\begin{array}{l}\text { Capture threshold values of } \leq 2.5 \mathrm{~V} \text { at } 0.5 \text {. } \\
\text { ms pulse width } \\
\text { Lead impedance measurements within } \\
\text { the programmed lead impedance limits } \\
\text { No diaphragmatic stimulation at a pacing } \\
\text { output of } 5.0 \mathrm{~V} \text { or } 7.5 \mathrm{~V} \text { and at a pulse } \\
\text { width of } 1.0 \mathrm{~ms} \text { if device will be } \\
\text { programmed to an asynchronous pacing } \\
\text { mode when MRI Settings are enabled }\end{array}$ & $\begin{array}{l}\text { Capture threshold } \leq 2.0 \mathrm{~V} \text { at } 0.4 \mathrm{~ms} \text { pulse } \\
\text { width } \\
\text { Lead impedance is between } 200 \text { and } \\
1500 \text { Ohms } \\
\text { Battery charging status: at least } 30 \%\end{array}$ \\
\hline
\end{tabular}

\begin{tabular}{|c|c|c|c|}
\hline $\begin{array}{l}\text { Programming } \\
\text { for MRI }\end{array}$ & MR conditional programming modes & MR conditional programming modes & MR conditional programming modes \\
\hline $\begin{array}{l}\text { Device } \\
\text { Identifiers }\end{array}$ & $\begin{array}{l}\text { Pulse generator radiopaque marking with } \\
\text { a unique symbol and three letter code } \\
\text { Unique radiopaque lead helix design }\end{array}$ & $\begin{array}{l}\text { A radio-opaque MRI symbol is present on } \\
\text { all implanted St. Jude MedicalTM MR } \\
\text { Conditional pacing system components } \\
\text { Radiopaque MR Conditional lead marker }\end{array}$ & $\begin{array}{l}\text { Pulse generator radiopaque marking. } \\
\text { No lead radiopaque identifier }\end{array}$ \\
\hline Scanner & 1.5 Tesla cylindrical bore MR system & $\begin{array}{l}1.5 \text { Tesla horizontal closed bore MR } \\
\text { system }\end{array}$ & 1.5 Tesla cylindrical bore MR system \\
\hline $\begin{array}{l}\text { Landmark } \\
\text { isocenter of RF } \\
\text { coil }\end{array}$ & $\begin{array}{l}\text { United States: Superior to C1 or inferior to } \\
\text { T12 } \\
\text { Ensura MRITM SureScanTM Pacing System } \\
\text { and Advisa DR MRITM SureScanTM } \\
\text { pacemaker labeling has no restrictions on } \\
\text { chest scans outside the United States }\end{array}$ & $\begin{array}{l}\text { Contraindication to use of local transmit- } \\
\text { only coils or local transmit and receive } \\
\text { coils placed directly over the pacing } \\
\text { system }\end{array}$ & $\begin{array}{l}\text { Maximum allowed positioning mark for } \\
\text { the isocenter starting from the foot at } \\
\text { the hip bone level. and maximum } \\
\text { allowed positioning mark for the } \\
\text { isocenter from the top of the skull at the } \\
\text { level of the eyes). }\end{array}$ \\
\hline $\begin{array}{l}\text { Patient } \\
\text { Positioning }\end{array}$ & $\begin{array}{l}\text { Contraindication to lateral decubitus } \\
\text { patient positioning }\end{array}$ & Must not be positioned on side & Dorsal position only. \\
\hline Scanner Mode & $\begin{array}{l}\text { Scanner in' the normal operating mode } \\
\text { (defined as the mode of operation of the } \\
\text { MR system in which none of the outputs } \\
\text { have a value that cause physiological } \\
\text { stress to patients) }\end{array}$ & $\begin{array}{l}\text { Scanner in the normal operating mode or } \\
\text { First Level Controlled operating mode }\end{array}$ & $\begin{array}{l}\text { The overall MR scanning time } \\
\text { accumulated from the imaging times as } \\
\text { displayed by the MRI scanner must not } \\
\text { exceed } 30 \text { minutes } \\
\text { The total accumulated length of } \\
\text { examination for the pacing system must } \\
\text { be below } 10 \text { hours }\end{array}$ \\
\hline $\begin{array}{l}\text { Radiofrequency } \\
\text { Energy }\end{array}$ & $\begin{array}{l}\text { Maximum gradient slew rate } \leq 200 \mathrm{~T} / \mathrm{m} / \mathrm{s} \\
\text { per axis } \\
\text { Whole body specific absorption rate (SAR) } \\
\text { levels } \leq 2 \mathrm{~W} / \mathrm{kg} \\
\text { Head SAR } \leq 3.2 \mathrm{~W} / \mathrm{kg}\end{array}$ & $\begin{array}{l}\text { Maximum gradient slew rate } \leq 200 \mathrm{~T} / \mathrm{m} / \mathrm{s} \\
\text { per axis } \\
\text { Whole body specific absorption rate (SAR) } \\
\leq 4.0 \mathrm{~W} / \mathrm{kg} \\
\text { Head } \mathrm{SAR} \leq 3.2 \mathrm{~W} / \mathrm{kg}\end{array}$ & $\begin{array}{l}\text { Maximum gradient slew rate } \leq 200 \mathrm{~T} / \mathrm{m} / \mathrm{s} \\
\text { per axis } \\
\text { Whole body specific absorption rate } \\
(\mathrm{SAR}) \leq 2.0 \mathrm{~W} / \mathrm{kg} \\
\text { Head } \mathrm{SAR} \leq 3.2 \mathrm{~W} / \mathrm{kg}\end{array}$ \\
\hline
\end{tabular}

content can be achieved through use of non-ferromagnetic conductive substances in the pacemaker generator. The leads are made of nonmagnetic materials. There are significant limitations on the choice of non-ferromagnetic materials, as the materials must be appropriately conductive, durable, and biocompatible.
An MRI-related factor which can decrease magnetic field interactions is the use of a lower magnetic field strength. Another factor is the maximization of the distance between the cardiac device and scanner during imaging. An example of this is a dedicated extremity MR system to scan the patient [17]. The further 
development of specialized scanners that utilize these factors may be useful $[17,89,90]$.

An additional magnetic field interaction is related to the effect of a static magnetic field of the MR system on the pacemaker reed switch. The reed switch is a feature in many pacemakers designed to program a pacemaker by means of a magnet placed over the device. Reed switch magnet responses in pacemakers may cause changes to a continuous asynchronous pacing mode (DOO or VOO) in order to avoid electromagnetic interactions during such procedures as surgery with the use of electrocautery (i.e., which generates electromagnetic interference) [91]. Reed switch activation associated with exposure to an MR system may not be predictable. It may vary with strength of the static magnetic field and with orientation of the reed switch to the magnetic field $[14,26,36]$. Given this unpredictability, an MR conditional pacemaker has been designed with replacement of the reed switch with a solid state Hall sensor [80,81]. The Hall sensor has a more predictable behavior when exposed to magnetic fields. Another pacemaker has a magnet detect sensor that prevents problems with the reed switch [92]. Future design related to magnetic field will need to also address higher field strengths $[57,59,93]$.

\section{Pacemaker Design and Electromagnetic Energy Conduction Issues}

Electromagnetic energy from the MR scanner can conduct through the pacing system or cause electrical interference with components of the system. Sources of this electromagnetic energy include the pulsed radiofrequency energy from a head or body coil and the time varying magnetic fields used by the MR system for spatial localization of signals. The transfer of radiofrequency energy to heat and electrical energy is dependent on factors including: 1) the pulse sequence parameters, 2) the whole body averaged and local specific absorption rates (SAR) associated with a given sequence, 3) spatial relation and orientation of the anatomy to the transmit RF coil, and 4) lead factors (composition, length, geometry, configuration, and orientation) [51,54,55,63,94-97].

Pacing leads can potentially act as antennae for electromagnetic energy impulses [27,98]. The transfer of electromagnetic energy can lead to myocardial electrical stimulation, tissue destruction at the lead tip/endocardial interface, pain, and damage to the pulse generator circuitry/battery. This may produce adverse effects on sensing, pacing thresholds, and lead impedances, and can cause inappropriate pacing acceleration or inhibition, and battery depletion $[4,6,7,9,20,29,31,33$, $36,41,43,50,52,61,62,98-100]$ In a recent investigation by Wilkoff et al. [81] on an MR conditional pacing system, these adverse effects were not observed. Pacing thresholds did not change significantly between patients with the device who were scanned and those who served as control patients.

Factors involved in pacemaker lead design relate to avoidance of the resonant frequency as well as the lead length, configuration, and position. As a lead can act as a receiver of electromagnetic impulses, avoiding the resonant frequency of a lead is of extreme importance. A resonant lead length has been associated with a greater heating effect [101].

A pacemaker lead is composed of an outer and inner insulation and an outer and inner lead coil. The lead coil is arranged in a configuration to maximize energy efficient conduction while maintaining flexibility, durability and minimization of lead diameter. The inner coil is made of filaments wound in a three-dimensional relationship coiled with a certain pitch. This has implications for MRI-related energy conduction based on the resonant frequency of the lead [35].

An example of lead design changes in an MR conditional lead is a lead modification due to a change in the pitch of the inner coil [102]. The inner coil was designed with a decreased number of coiled filars, increasing the number of winding turns and, therefore, increasing the lead inductance. This geometry limits the radiofrequencies that can conduct through the lead filaments. The decrease in the number of filars required an increase in the filar diameter to increase the strength of the lead. Additionally, a lead tip coating was used with a substance that decreased polarization. As unipolar pacing is more susceptible to the MRI environment, a bipolar lead design was used so that the generator was not essential to the pacing circuit $[21,43]$.

Measurements of lead heating with in vitro models can be challenging [103]. In models, many factors affect heating at the lead tip including length and the geometric structure of the lead, phantom shape, and position of the radiofrequency coil. Closer proximity of leads to the edge of the phantom and to the edge of the coil caused greatest heating [55]. Another phantom study at $1.5 \mathrm{~T}$ demonstrated greatest heating with the torso centered along the superior-inferior direction of the transmit coil [97]. In vitro study of lead design has demonstrated increased heating with increased lead insulation thickness and uncoiled leads of $25-50 \mathrm{~cm}$ length [104]. This study demonstrated decreased heating with increased lead impedance and winding configuration with reversed winding segments.

Abandoned leads can also conduct radiofrequency energy. In an in vivo study of clinical lead lengths (40$60 \mathrm{~cm}$ ), abandoned leads demonstrated greater lead tip heating in comparison to leads attached to pulse generators [68]. Therefore, no additional abandoned leads 
should be present [81]. As interactions can occur with abandoned leads, special attention to the patient's device history regarding abandoned leads is important.

Circuitry filters to impede or limit the transfer of certain frequencies, circuits that divert and dissipate energy, and generator shielding can also be important to design in order to avoid or minimize the transfer of electromagnetic energy. Of note, retained epicardial wires cut short at the skin level from previous cardiothoracic surgery procedures do not appear to be associated with serious MRI-related issues [105,106].

\section{Application of Defined MR Conditions}

Of paramount importance to the implementation of these new technologies is the education and training of the medical community involved in care of cardiac device patients who are undergoing MR scans. The goals of education are to provide optimal patient care and efficient patient flow in the MR center. This includes understanding of the pacemaker programming to an MR conditional mode. The design of the programming hardware and software must include features to inactivate sensing, internal assessment of system integrity, and clear programming return to pre-scan values.

The decision as to the appropriate pacing mode during MR scanning requires arrhythmia expertise. Understanding of the patient's initial indication for the device, arrhythmia history, and underlying rhythm/pacemaker dependence are important aspects of clinical information. The underlying sinus rate, AV nodal conduction, and presence rate and location of escape rhythms are important in making decisions as to the appropriate programming mode (Figure 1). Additionally, many pacemakers have logs listing the percentage of time that a patient is paced in the atrium or ventricle. One needs to interpret this data though in regard to the programmed pacing rate and programmed AV intervals, as the patient may have a regular rhythm under these programmed parameters. As predicting bradyarrhythmic or tachyarrhythmic events on a beat by beat basis is challenging, even when the appropriate mode is chosen based on past history, meticulous and continuous monitoring of the patient's heart rate and rhythm is required while the patient is programmed in the appropriate MR conditional mode. Asynchronous pacing is used with scanning a pacemaker dependent patient. In those patients with an underlying rhythm who are not bradycardic, a ventricular rate competing with the asynchronous pacing could lead to pacing during ventricular repolarization, potentially causing an $\mathrm{R}$ on $\mathrm{T}$ phenomenon leading to life threatening ventricular arrhythmias $[36,107,108]$.

The pacemaker programmer device must be outside of the MR scanner room. Device programming immediately before entering the MRI environment and device interrogation and reprogramming immediately after removal from the MRI environment can limit the amount of time that the patient is in the MR conditional mode. Before MRI scanning, the initial programming mode is stored, so that devices can be programmed back to the original settings.

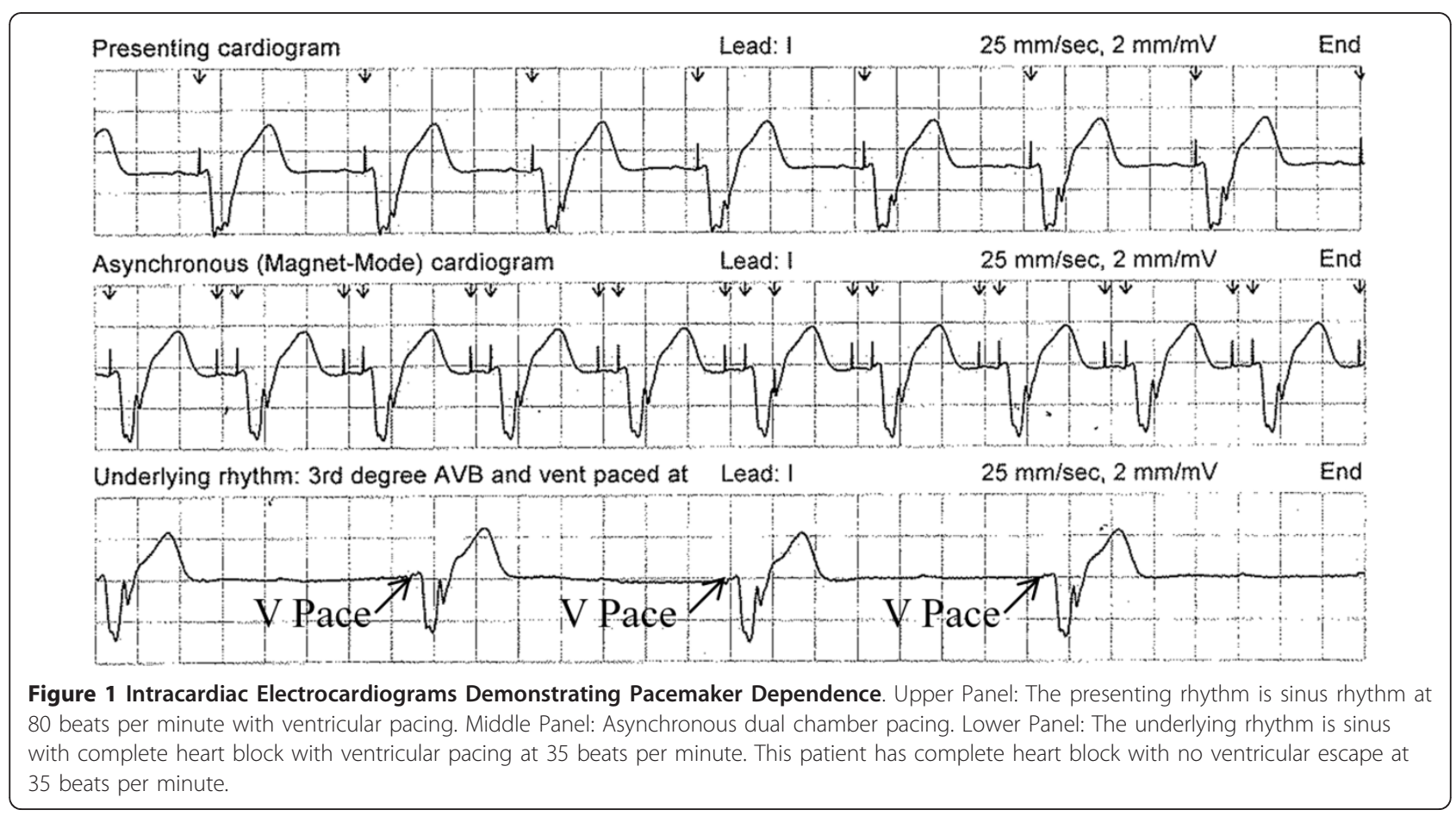


Even with advances in use of MR conditional ECG monitoring equipment, the MRI environment causes artifacts in the recordings. Therefore, meticulous attention to ECG electrode pad positioning and skin prep must be performed to assure adequate monitoring $[109,110]$. Visual and verbal assessment of the patient's level of consciousness, blood pressure and pulse oximetry monitoring provide additional mechanisms to alert the MRI technologists, nurses, and/or physician of any unusual sensations or issues. The presence of healthcare professionals who have completed training in the programming and scanning of the specific MR conditional device and availability of a defibrillator (albeit, to be used outside of the MR system room), are essential.

Although scanning a patient with an MR conditional device following the strict patient and MRI-related conditions appears straightforward, issues that impact patients with pre-existing devices remain complex. Until MR conditional devices are the routine platform for all of these devices, there will still be challenging decisions regarding using MRI in patients with pre-existing devices where imaging is required to diagnose and manage a potentially life threatening scenario, such as a central nervous system tumor, cord compression, stroke or hemorrhage $[44,47,60]$. The previous database for nonMR conditional devices is, therefore, still important in individualizing the risk:benefit ratio in these challenging circumstances $[1,69,111,112]$.

As the MR conditional system was designed for the pulse generator to be used only with the MR conditional leads, an MR conditional generator cannot be simply attached to pre-existing leads and retain MR conditional labeling. A decision would need to be made as to whether to scan the patient with their pre-existing system or whether to extract the pacing system and place an MR conditional cardiac pacemaker. Because there can be significant complications with system extraction and replacement, including vascular damage, cardiac perforation, infection, etc., the risk:benefit ratio of these options needs to be carefully decided by physicians with expertise in these areas [113]. Additional questions will relate to the best approach to generator change-outs in patients at elective replacement who will likely require MRI procedures in the future, recognizing that change to a MR conditional system requires explant of the entire system including leads and implant of new system.

\section{Special Design Issues Related to ICDs}

Data related to the use of MRI in patients with ICDs are limited with variable results, with some isolated reports demonstrating no significant effects while others described issues with ability to communicate with the ICD post scan, sensing of electromagnetic noise, and changes in battery voltage $[22,28,34,39,44,46-48$, $53,56,61,88,100]$. ICDs possess additional complexity compared to pacemakers due to the larger size and complexity of leads, circuitry related to arrhythmia detection and treatment, and capacitors for cardioversion and defibrillation [114-116].

The increased ferromagnetic content of ICDs compared to pacemakers will require special attention to design and study of magnetic field interaction issues. Magnetic field interactions with the magnet response of many ICDs may cause inactivation of arrhythmia detection leading to inhibition of ICD therapies. Reliable magnetic responses in the MRI environment will need to be assessed as well as programming to ensure that ICD antitachycardia pacing, cardioversion and defibrillation therapies are not attempted by the ICD while the patient is in the MR scanner.

With ICDs, transmitted electromagnetic currents associated with MRI could potentially trigger tachyarrhythmia detection, if detection is not programmed to the "off" mode before MRI. It is unclear, though, whether ICD capacitors can charge in the presence of the MR system's powerful static magnetic field [46]. ICD programming in the MRI environment will require reliable and clear mechanisms to deactivate sensing modes to avoid inappropriate sensing of radiofrequency energy, as well as programming of pacing modes along the lines of MR conditional pacemakers.

Special intra-scan issues related to ICDs stem from the fact that these patients typically have an underlying cardiac substrate predisposing them to potentially life threatening ventricular arrhythmias. The arrhythmia history regarding the frequency of arrhythmias and overall cardiovascular patient stability are important, and these patients require meticulous monitoring while therapies are inactivated during an MRI examination. Programming design will also need to provide straight forward mechanisms to activate and confirm the original programming post-scan. The need for post-scanning ICD defibrillation threshold testing is another issue which warrants further assessment [117].

\section{Future Issues Related to the Spectrum of Cardiac Devices and Scanners}

Given the expanding role of biomedical devices in diagnosis and treatment of medical conditions, design and engineering will play an important role in the future of many technologies as they relate to the MRI environment [118]. The gamut of cardiac devices includes atrial/biventricular and biventricular pacemakers and ICDs, subcutaneous ICDs, arrhythmia monitors and implantable physiologic measurement devices, and temporary pacing systems. Each of these technologies has a different lead number, shape, size and location, as well 
as generator function, size, and geometry. Additionally, neuromodulation devices (including those devices used for vagus nerve stimulation, deep brain stimulation, spinal cord stimulation, and stimulation of other organs) derived from cardiac pacemaker technologies are being implanted in patients with potential problematic MRI interactions and, thus, the need for further design modifications [119-125].

MRI is also utilized to direct such procedures as cardiac vascular/valvular interventions, cardiac electrophysiology procedures, biopsy, surgical, ablative, cryogenic, directed chemotherapeutic procedures, and neuromodulation treatments [126-137]. Biomedical device design changes will be necessary to allow the use of these technologies when they are MR-guided to avoid device/imaging interactions $[138,139]$.

Design and engineering will not only need to take into account safety, but also: 1) the effect of MR conditional devices on diagnostic quality of the MR images, 2) application to cardiac imaging, 3) cost effectiveness and 4) impact on overall patient care. As MRI artifacts principally affect the local region of implanted devices, for pacemakers, ICDS, and other cardiac biomedical devices, artifact issues will be most important to cardiovascular and thoracic imaging $[31,39,64,140]$. The currently released MR conditional pacemaker in the United States requires specific landmarking steps be taken to acquire cardiac images, although not in Europe. In the European Community, the Biotronik system has a scan exclusion zone with the maximum allowed positioning mark for the isocenter starting from the foot at the hip bone level and the maximum allowed positioning mark for the isocenter from the top of the skull at the level of the eyes, while the St. Jude system specifies contraindication only to the transmit-only or local transmit and receive coils directly over the pacing system $[81,86,87]$.

Both isocenter and artifact issues are important to the future of cardiac imaging using MR conditional pacemakers. Regarding artifacts from the pacer components, there is no easy solution, as gradient echo and steady state free precession images may be significantly distorted by regional changes in magnetic field homogeneity. For MRI examinations involving the region of the thorax, issues related to artifacts (i.e., both signal loss and image distortion) will obviously have great importance. In one study of patients with cardiac pacemakers or ICDs, $93 \%$ of thoracic scans were diagnostically acceptable [47].

Regarding chest imaging, issues of stress testing necessitate further investigation. The underlying lack of chronotropic competence in many patients with pacemakers and well as current programming algorithms with fixed pacing rates or programmed off for MR conditional pacemakers could be challenging for studies which require an elevation to $85 \%$ of the maximum of heart rate with stress. Coronary vasodilator stress would appear to be the most practical approach, but require further study. As with many new technologies, decisions regarding implementation in populations, cost, reimbursement and continued future design systems will need to be investigated (Table 3).

\section{Conclusions}

The advancement of MR conditional technology has led to greater options for patient management and has also resulted in greater complexity of clinical issues. The current MR conditional pacing technology provides definite solutions to some specific issues related to MR scanning. Future design, engineering, testing, and

Table 3 Issues Raised by the Advent of MR Conditional Cardiac Devices Which Require Further Study.

\begin{tabular}{|c|c|}
\hline Patient Selection & $\begin{array}{l}\text { Who should receive MR conditional devices? } \\
\text { Should MR conditional devices become the standard platform or used only in those patients with a higher risk of needing } \\
\text { MR scanning in the future? } \\
\text { Who is at highest risk of needing future MR scanning? }\end{array}$ \\
\hline $\begin{array}{l}\text { Medical } \\
\text { Coordination }\end{array}$ & $\begin{array}{l}\text { What are the most efficient and safest algorithms for coordination of medical staff from multiple disciplines (radiology, } \\
\text { cardiology, cardiac electrophysiology, pacemaker technicians, MR technicians), in assessing, monitoring, and scanning } \\
\text { patients? }\end{array}$ \\
\hline $\begin{array}{l}\text { Study Type and } \\
\text { Quality }\end{array}$ & $\begin{array}{l}\text { What is the spectrum of MR studies that can be performed with MR conditional cardiac devices regarding study types, } \\
\text { imaging sequences, and the use of stress testing? } \\
\text { What is the impact of MR conditional devices on image quality? } \\
\text { How can cardiac MR imaging be performed with MR conditional devices? }\end{array}$ \\
\hline Impact on Care & $\begin{array}{l}\text { Does use of MR conditional cardiac devices improve the quality of patient care? } \\
\text { What is the optimal approach to MR scanning in a patient with a non-MR conditional device in place regarding risks of } \\
\text { extraction and replacement versus scanning with the implanted system? }\end{array}$ \\
\hline Cost & $\begin{array}{l}\text { What is the impact of implantation of MR conditional devices on device cost, physician and technologist time and cost for } \\
\text { assessment and monitoring of patients? } \\
\text { How should reimbursement and reimbursement codes for system placement and peri-scanning monitoring/device } \\
\text { assessment be determined? }\end{array}$ \\
\hline
\end{tabular}


implementation of systems will need to focus on a goal of broadening these applications to further decreasing the barriers to scanning patients with cardiac and noncardiac, electronically-activated devices. Although the current literature provides data on the first generation of MR conditional cardiac pacemakers from multi-center trials conducted at research centers, post market data will be essential to assess impact of implementation of this technology in "real world" scenarios and provide long term data on the function of these systems [102,141]. The impact of MR conditional pacemakers will also be dependent on implant rates of pacemakers versus ICDs, which vary by country [142]. Further research is required on multiple issues related to MRI interactions with devices, including, the effects of multiple scans on these systems and system effects at higher static magnetic field strengths [102]. The design, development, study and implementation of cardiovascular MR conditional devices will continue to require the expertise and collaboration of multiple disciplines and will need to prove safety, effectiveness and cost effectiveness in patient care.

\section{Author details \\ 'Division of Cardiovascular Medicine/Cardiovascular and Thoracic Institute, Keck School of Medicine, University of Southern California, Los Angeles, CA 90033, USA. ${ }^{2}$ Department of Radiology, Keck School of Medicine, University of Southern California, Los Angeles, CA90033, USA.}

\section{Authors' contributions}

JSS participated in writing and editing of the manuscript, providing perspective from the Cardiology standpoint. PMC participated in writing and editing of the manuscript, providing perspective from the Radiology standpoint. FGS participated in writing and editing of the manuscript, providing perspective from the MR safety standpoint. All authors read and approved the final manuscript.

\section{Competing interests}

Frank G. Shellock is a consultant for Medtronic. Boston Scientific, Biotronik, and St. Jude Medical. Jerold S. Shinbane and Patrick M. Colletti have no conflicts of interest.

Received: 24 May 2011 Accepted: 27 October 2011

Published: 27 October 2011

\section{References}

1. Shinbane JS, Colletti PM, Shellock FG: MR in patients with pacemakers and ICDs: Defining the issues. J Cardiovasc Magn Reson 2007, 9(1):5-13.

2. Kalin R, Stanton MS: Current clinical issues for MRI scanning of pacemaker and defibrillator patients. Pacing Clin Electrophysiol 2005, 28(4):326-328.

3. Shellock FG, Woods TO, Crues JV: MR labeling information for implants and devices: explanation of terminology. Radiology 2009, 253(1):26-30.

4. Pavlicek W, Geisinger M, Castle L, Borkowski GP, Meaney TF, Bream BL, Gallagher JH: The effects of nuclear magnetic resonance on patients with cardiac pacemakers. Radiology 1983, 147(1):149-153.

5. Fetter J, Aram G, Holmes DR, Gray JE, Hayes DL: The effects of nuclear magnetic resonance imagers on external and implantable pulse generators. Pacing Clin Electrophysiol 1984, 7(4):720-727.

6. Erlebacher JA, Cahill PT, Pannizzo F, Knowles RJ: Effect of magnetic resonance imaging on DDD pacemakers. Am J Cardiol 1986, 57(6):437-440.
7. Holmes DR Jr, Hayes DL, Gray JE, Merideth J: The effects of magnetic resonance imaging on implantable pulse generators. Pacing Clin Electrophysiol 1986, 9(3):360-370.

8. Iberer F, Justich E, Stenzl W, Tscheliessnig KH, Kapeller J: Nuclear magnetic resonance imaging of a patient with implanted transvenous pacemaker. Herz 1987, 7:196-199.

9. Hayes DL, Holmes DR Jr, Gray JE: Effect of 1.5 tesla nuclear magnetic resonance imaging scanner on implanted permanent pacemakers. J Am Coll Cardiol 1987, 10(4):782-786.

10. Avery JK: Loss Prevention case of the month. Not my responsibility! $J$ Tenn Med Assoc 1988, 81(8):523.

11. Alagona P Jr, Toole JC, Maniscalco BS, Glover MU, Abernathy GT, Prida XE: Nuclear magnetic resonance imaging in a patient with a DDD Pacemaker. Pacing Clin Electrophysiol 1989, 12(4 Pt 1):619.

12. Inbar S, Larson J, Burt T, Mafee M, Ezri MD: Case report: nuclear magnetic resonance imaging in a patient with a pacemaker. Am J Med Sci 1993, 305(3):174-175.

13. Amar D, Gross JN: Pacemaker interactions with transcutaneous cardiac pacing. Anesthesiology 1994, 80(3):717-718.

14. Lauck G, von Smekal A, Wolke S, Seelos KC, Jung W, Manz M, Luderitz B: Effects of nuclear magnetic resonance imaging on cardiac pacemakers. Pacing Clin Electrophysiol 1995, 18(8):1549-1555.

15. Gimbel JR, Johnson D, Levine PA, Wilkoff BL: Safe performance of magnetic resonance imaging on five patients with permanent cardiac pacemakers. Pacing Clin Electrophysiol 1996, 19(6):913-919.

16. Garcia-Bolao I, Albaladejo V, Benito A, Alegria E, Zubieta JL: Magnetic resonance imaging in a patient with a dual-chamber pacemaker. Acta Cardiol 1998, 53(1):33-35.

17. Shellock FG, O'Neil M, Ivans V, Kelly D, O'Connor M, Toay L, Crues JV: Cardiac pacemakers and implantable cardioverter defibrillators are unaffected by operation of an extremity MR imaging system. AJR Am J Roentgenol 1999, 172(1):165-170.

18. Sommer T, Vahlhaus C, Lauck G, von Smekal A, Reinke M, Hofer U, Block W, Traber F, Schneider C, Gieseke J, Jung W, Schild H: MR imaging and cardiac pacemakers: in-vitro evaluation and in-vivo studies in 51 patients at 0.5 T. Radiology 2000, 215(3):869-879.

19. Luechinger R, Duru F, Scheidegger MB, Boesiger P, Candinas R: Force and torque effects of a 1.5-Tesla MRI scanner on cardiac pacemakers and ICDs. Pacing Clin Electrophysiol 2001, 24(2):199-205.

20. Vahlhaus C, Sommer T, Lewalter T, Schimpf R, Schumacher B, Jung W, Luderitz B: Interference with cardiac pacemakers by magnetic resonance imaging: are there irreversible changes at 0.5 Tesla? Pacing Clin Electrophysiol 2001, 24(4 Pt 1):489-495.

21. Scholten A, Silny J: The interference threshold of unipolar cardiac pacemakers in extremely low frequency magnetic fields. J Med Eng Technol 2001, 25(5):185-194.

22. Anfinsen OG, Berntsen RF, Aass H, Kongsgaard E, Amlie JP: Implantable cardioverter defibrillator dysfunction during and after magnetic resonance imaging. Pacing Clin Electrophysiol 2002, 25(9):1400-1402.

23. Dawson TW, Caputa K, Stuchly MA, Shepard RB, Kavet R, Sastre A: Pacemaker interference by magnetic fields at power line frequencies. IEEE Trans Biomed Eng 2002, 49(3):254-262

24. Greatbatch W, Miller V, Shellock FG: Magnetic resonance safety testing of a newly-developed fiber-optic cardiac pacing lead. J Magn Reson Imaging 2002, 16(1):97-103.

25. Irnich W: Electronic security systems and active implantable medical devices. Pacing Clin Electrophysiol 2002, 25(8):1235-1258.

26. Luechinger $R$, Duru F, Zeijlemaker VA, Scheidegger MB, Boesiger $P$, Candinas R: Pacemaker reed switch behavior in $0.5,1.5$, and 3.0 Tesla magnetic resonance imaging units: are reed switches always closed in strong magnetic fields? Pacing Clin Electrophysiol 2002, 25(10):1419-1423.

27. Pictet J, Meuli R, Wicky S, van der Klink JJ: Radiofrequency heating effects around resonant lengths of wire in MRI. Phys Med Biol 2002, 47(16):2973-2985.

28. Fiek M, Remp T, Reithmann C, Steinbeck G: Complete loss of ICD programmability after magnetic resonance imaging. Pacing Clin Electrophysiol 2004, 27(7):1002-1004.

29. Martin ET, Coman JA, Shellock FG, Pulling CC, Fair R, Jenkins K: Magnetic resonance imaging and cardiac pacemaker safety at 1.5-Tesla. J Am Coll Cardiol 2004, 43(7):1315-1324. 
30. Coman JA, Martin ET, Sandler DA, Thomas RT: Implantable cardiac defibrillator interactions with magnetic resonance imaging at 1.5 tesla. $J$ Am Coll Cardiol 2004, 43(5):138A.

31. Roguin A, Zviman MM, Meininger GR, Rodrigues ER, Dickfeld TM, Bluemke DA, Lardo A, Berger RD, Calkins H, Halperin HR: Modern pacemaker and implantable cardioverter/defibrillator systems can be magnetic resonance imaging safe: in vitro and in vivo assessment of safety and function at 1.5 T. Circulation 2004, 110(5):475-482.

32. Del Ojo JL, Moya F, Villalba J, Sanz O, Pavon R, Garcia D, Pastor L: Is magnetic resonance imaging safe in cardiac pacemaker recipients? Pacing Clin Electrophysiol 2005, 28(4):274-278.

33. Gimbel JR, Bailey SM, Tchou PJ, Ruggieri PM, Wilkoff BL: Strategies for the safe magnetic resonance imaging of pacemaker-dependent patients. Pacing Clin Electrophysiol 2005, 28(10):1041-1046.

34. Gimbel JR, Kanal E, Schwartz KM, Wilkoff BL: Outcome of magnetic resonance imaging (MRI) in selected patients with implantable cardioverter defibrillators (ICDs). Pacing Clin Electrophysiol 2005, 28(4):270-273.

35. Gray RW, Bibens WT, Shellock FG: Simple design changes to wires to substantially reduce MRI-induced heating at $1.5 \mathrm{~T}$ : implications for implanted leads. Magn Reson Imaging 2005, 23(8):887-891.

36. Irnich W, Irnich B, Bartsch C, Stertmann WA, Gufler H, Weiler G: Do we need pacemakers resistant to magnetic resonance imaging? Europace 2005, 7(4):353-365

37. Luechinger R, Zeijlemaker VA, Pedersen EM, Mortensen P, Falk E, Duru F, Candinas $R$, Boesiger $P$ : In vivo heating of pacemaker leads during magnetic resonance imaging. Eur Heart J 2005, 26(4):376-383, discussion 325-377.

38. Maldonado JG, Pereira ME, Albuquerque KR, Pires J: Magnetic resonance imaging in a patient with pacemaker. Arq Bras Cardiol 2005, 84(5):428-430.

39. Roguin A, Donahue JK, Bomma CS, Bluemke DA, Halperin HR: Cardiac magnetic resonance imaging in a patient with implantable cardioverterdefibrillator. Pacing Clin Electrophysiol 2005, 28(4):336-338.

40. Roguin A, Zviman MM, Halperin HR: Re.Complete loss of ICD programmability after magnetic resonance imaging. Pacing Clin Electrophysiol 2005, 28(4):354, author reply 354-355.

41. Rozner MA, Burton AW, Kumar A: Pacemaker complication during magnetic resonance imaging. J Am Coll Cardiol 2005, 45(1):161-162, author reply 162 .

42. Schmiedel A, Hackenbroch M, Yang A, Nahle CP, Skowasch D, Meyer C, Schimpf $\mathrm{R}$, Schild $\mathrm{H}$, Sommer $\mathrm{T}$ : Magnetic resonance imaging of the brain in patients with cardiac pacemakers. Experimental and clinical investigations at 1.5 Tesla. Rofo 2005, 177(5):731-744.

43. Trigano A, Blandeau O, Souques M, Gernez JP, Magne I: Clinical study of interference with cardiac pacemakers by a magnetic field at power line frequencies. J Am Coll Cardiol 2005, 45(6):896-900.

44. Wollmann C, Grude M, Tombach B, Kugel H, Heindel W, Breithardt G, Bocker D, Vahlhaus C: Safe performance of magnetic resonance imaging on a patient with an ICD. Pacing Clin Electrophysiol 2005, 28(4):339-342.

45. Mattei E, Calcagnini G, Triventi M, Censi F, Bartolini P, Kainz W, Bassen H: MRI induced heating of pacemaker leads: effect of temperature probe positioning and pacemaker placement on lead tip heating and local SAR. Conf Proc IEEE Eng Med Biol Soc 2006, 1:1889-1892.

46. Naehle CP, Sommer T, Meyer C, Strach K, Kreuz J, Litt H, Lewalter T, Schild H, Schwab JO: Strategy for safe performance of magnetic resonance imaging on a patient with implantable cardioverter defibrillator. Pacing Clin Electrophysiol 2006, 29(1):113-116.

47. Nazarian S, Roguin A, Zviman MM, Lardo AC, Dickfeld TL, Calkins H, Weiss RG, Berger RD, Bluemke DA, Halperin HR: Clinical utility and safety of a protocol for noncardiac and cardiac magnetic resonance imaging of patients with permanent pacemakers and implantable-cardioverter defibrillators at 1.5 tesla. Circulation 2006, 114(12):1277-1284.

48. Nemec J: Suppression of implantable cardioverter defibrillator therapy during magnetic resonance imaging. J Cardiovasc Electrophysiol 2006, 17(4):444-445.

49. Shellock FG, Fieno DS, Thomson LJ, Talavage TM, Berman DS: Cardiac pacemaker: in vitro assessment at 1.5 T. Am Heart J 2006, 151(2):436-443.

50. Sommer T, Naehle CP, Yang A, Zeijlemaker V, Hackenbroch M, Schmiedel A, Meyer C, Strach K, Skowasch D, Vahlhaus C, Litt H, Schild H: Strategy for safe performance of extrathoracic magnetic resonance imaging at 1.5 tesla in the presence of cardiac pacemakers in non-pacemaker- dependent patients: a prospective study with 115 examinations. Circulation 2006, 114(12):1285-1292.

51. Babouri A, Hedjeidj A: In vitro investigation of eddy current effect on pacemaker operation generated by low frequency magnetic field. Conf Proc IEEE Eng Med Biol Soc 2007, 2007:5684-5687.

52. Heatlie G, Pennell DJ: Cardiovascular magnetic resonance at $0.5 T$ in five patients with permanent pacemakers. J Cardiovasc Magn Reson 2007, 9(1):15-19.

53. Shellock FG, Fischer L, Fieno DS: Cardiac pacemakers and implantable cardioverter defibrillators: in vitro magnetic resonance imaging evaluation at 1.5-tesla. J Cardiovasc Magn Reson 2007, 9(1):21-31.

54. Calcagnini G, Triventi M, Censi F, Mattei E, Bartolini P, Kainz W, Bassen HI: In vitro investigation of pacemaker lead heating induced by magnetic resonance imaging: role of implant geometry. J Magn Reson Imaging 2008, 28(4):879-886.

55. Mattei E, Triventi M, Calcagnini G, Censi F, Kainz W, Mendoza G, Bassen HI, Bartolini P: Complexity of MRI induced heating on metallic leads: experimental measurements of 374 configurations. Biomed Eng Online 2008, 7:11.

56. Mollerus M, Albin G, Lipinski M, Lucca J: Cardiac biomarkers in patients with permanent pacemakers and implantable cardioverter-defibrillators undergoing an MRI scan. Pacing Clin Electrophysiol 2008, 31(10):1241-1245.

57. Naehle CP, Meyer C, Thomas D, Remerie S, Krautmacher C, Litt H, Luechinger R, Fimmers R, Schild H, Sommer T: Safety of brain 3-T MR imaging with transmit-receive head coil in patients with cardiac pacemakers: pilot prospective study with 51 examinations. Radiology 2008, 249(3):991-1001.

58. Tandri H, Zviman MM, Wedan SR, Lloyd T, Berger RD, Halperin H: Determinants of gradient field-induced current in a pacemaker lead system in a magnetic resonance imaging environment. Heart Rhythm 2008, 5(3):462-468.

59. Gimbel JR: Unexpected asystole during $3 T$ magnetic resonance imaging of a pacemaker-dependent patient with a 'modern' pacemaker. Europace 2009, 11(9):1241-1242.

60. Goldsher D, Jahshan S, Roguin A: Successful cervical MR scan in a patient several hours after pacemaker implantation. Pacing Clin Electrophysiol 2009, 32(10):1355-1356.

61. Mollerus M, Albin G, Lipinski M, Lucca J: Ectopy in patients with permanent pacemakers and implantable cardioverter-defibrillators undergoing an MRI scan. Pacing Clin Electrophysio/ 2009, 32(6):772-778.

62. Naehle CP, Zeijlemaker V, Thomas D, Meyer C, Strach K, Fimmers R, Schild H, Sommer T: Evaluation of cumulative effects of MR imaging on pacemaker systems at 1.5 Tesla. Pacing Clin Electrophysiol 2009, 32(12):1526-1535.

63. Nordbeck P, Weiss I, Ehses P, Ritter O, Warmuth M, Fidler F, Herold V Jakob PM, Ladd ME, Quick HH, Bauer WR: Measuring RF-induced currents inside implants: Impact of device configuration on MRI safety of cardiac pacemaker leads. Magn Reson Med 2009, 61(3):570-578.

64. Pulver AF, Puchalski MD, Bradley DJ, Minich LL, Su JT, Saarel EV, Whitaker P, Etheridge SP: Safety and imaging quality of MRI in pediatric and adult congenital heart disease patients with pacemakers. Pacing Clin Electrophysiol 2009, 32(4):450-456.

65. Shellock FG: Excessive temperature increases in pacemaker leads at 3-T MR imaging with a transmit-receive head coil. Radiology 2009, 251(3):948-949, author reply 949-950.

66. Millar LM, Robinson AG, O'Flaherty MT, Eames N, Johnston N, Heyburn G: Magnetic Resonance Imaging in a Patient with a Dual Chamber Pacemaker. Case Report Med 2010, 2010:292071.

67. Strach K, Naehle CP, Muhlsteffen A, Hinz M, Bernstein A, Thomas D, Linhart M, Meyer C, Bitaraf S, Schild H, Sommer T: Low-field magnetic resonance imaging: increased safety for pacemaker patients? Europace 2010, 12(7):952-960.

68. Langman DA, Goldberg IB, Finn JP, Ennis DB: Pacemaker lead tip heating in abandoned and pacemaker-attached leads at 1.5 tesla MRI. J Magn Reson Imaging 2011, 33(2):426-431.

69. Zikria JF, Machnicki S, Rhim E, Bhatti T, Graham RE: MRI of patients with cardiac pacemakers: a review of the medical literature. AJR Am J Roentgenol 2011, 196(2):390-401.

70. Cohen JD, Costa HS, Russo RJ: Determining the risks of MRI at 1.5-Tesla for patients with pacemakers and implantable cardioberter defibrillators (The MagnaSafe Registry). Circulation 2010, 122:A21241. 
71. The MagnaSafe Registry: Determining the Risks of Magnetic Resonance Imaging (MRI) in the Presence of Pacemakers and Implantable Cardioverter Defibrillators (ICDs). [http://clinicaltrials.gov], (NCT00907361).

72. Faris OP, Shein MJ: Government viewpoint: U.S. Food \& Drug Administration: Pacemakers, ICDs and MRI. Pacing Clin Electrophysiol 2005, 28(4):268-269.

73. Smith JM: Industry viewpoint: Guidant: Pacemakers, ICDs, and MRI. Pacing Clin Electrophysiol 2005, 28(4):264.

74. Stanton MS: Industry viewpoint: Medtronic: Pacemakers, ICDs, and MRI. Pacing Clin Electrophysiol 2005, 28(4):265.

75. Levine PA: Industry viewpoint: St. Jude Medical: Pacemakers, ICDs and MRI. Pacing Clin Electrophysiol 2005, 28(4):266-267.

76. Fisher JD: MRI: safety in patients with pacemakers or defibrillators: is it prime time yet? Pacing Clin Electrophysiol 2005, 28(4):263.

77. Martin ET: Can cardiac pacemakers and magnetic resonance imaging systems co-exist? Eur Heart J 2005, 26(4):325-327.

78. Faris OP, Shein M: Food and Drug Administration perspective: Magnetic resonance imaging of pacemaker and implantable cardioverterdefibrillator patients. Circulation 2006, 114(12):1232-1233.

79. Wilkoff BL: Pacemaker and ICD malfunction-an incomplete picture. JAMA 2006, 295(16):1944-1946.

80. Sutton R, Kanal E, Wilkoff BL, Bello D, Luechinger R, Jenniskens I, Hull M, Sommer T: Safety of magnetic resonance imaging of patients with a new Medtronic EnRhythm MRI SureScan pacing system: clinical study design. Trials 2008, 9:68.

81. Wilkoff BL, Bello D, Taborsky M, Vymazal J, Kanal E, Heuer H, Hecking K, Johnson WB, Young W, Ramza B, Akhtar N, Kuepper B, Hunold P, Luechinger R, Puererfellner H, Duru F, Gotte MJ, Sutton R, Sommer T: Magnetic resonance imaging in patients with a pacemaker system designed for the magnetic resonance environment. Heart Rhythm 2011, 8(1):65-73.

82. Forleo GB, Santini L, Della Rocca DG, Romano V, Papavasileiou LP, Magliano G, Sgueglia M, Romeo F: Safety and efficacy of a new magnetic resonance imaging-compatible pacing system: early results of a prospective comparison with conventional dual-chamber implant outcomes. Heart Rhythm 2010, 7(6):750-754.

83. Advisa MRI Clinical Study. [http://clinicaltrials.gov], (NCT01110915).

84. Clinical Evaluation of the Sorin Group's REPLY MR-conditional Pacing System. [http://clinicaltrials.gov], (NCT01341522).

85. Standard Practice for Marking Medical Devices and Other Items for Safety in the Magnetic Resonance Environment. American Society for Testing and Materials (ASTM) International 2003, F2503-05(West Conshohocken, PA)..

86. St. Jude User's Manual: Tendril MRITM ${ }^{\mathrm{TM}}$ Accent MRI ${ }^{\mathrm{TM}}$, Accent ST MRI ${ }^{\mathrm{TM}}$, SJM MRI Activator ${ }^{\mathrm{TM}}$. [http://www.sjm.com].

87. Biotronik User's Manual: ProMRITM. [http://:www.biotronik.com].

88. Shellock FG, Tkach JA, Ruggieri PM, Masaryk TJ: Cardiac pacemakers, ICDs, and loop recorder: evaluation of translational attraction using conventional ("long-bore") and "short-bore" 1.5- and 3.0-Tesla MR systems. J Cardiovasc Magn Reson 2003, 5(2):387-397.

89. Shellock FG, Bert JM, Fritts HM, Gundry CR, Easton R, Crues JV: Evaluation of the rotator cuff and glenoid labrum using a 0.2-Tesla extremity magnetic resonance (MR) system: MR results compared to surgical findings. J Magn Reson Imaging 2001, 14(6):763-770.

90. Zlatkin MB, Hoffman C, Shellock FG: Assessment of the rotator cuff and glenoid labrum using an extremity MR system: MR results compared to surgical findings from a multi-center study. J Magn Reson Imaging 2004, 19(5):623-631.

91. Driller J, Barold SS, Parsonnet V: Normal and abnormal function of the pacemaker magnetic reed switch. J Electrocardiol 1976, 9(3):283-292.

92. Shellock FG, Fischer L, Fieno D: Cardiac pacemakers and implantable cardioverter defibrillators: in vitro MRI evaluation at 1.5-Tesla. J Cardiovasc Magn Reson 2007, 9(1):21-31.

93. Gimbel JR: Unexpected pacing inhibition upon exposure to the 3T static magnetic field prior to imaging acquisition: What is the mechanism? Heart Rhythm 2011, 8(6):944-945.

94. Park SM, Kamondetdacha R, Nyenhuis JA: Calculation of MRI-induced heating of an implanted medical lead wire with an electric field transfer function. J Magn Reson Imaging 2007, 26(5):1278-1285.

95. Yeung CJ, Karmarkar P, McVeigh ER: Minimizing RF heating of conducting wires in MRI. Magn Reson Med 2007, 58(5):1028-1034.
96. Nordbeck P, Fidler F, Weiss I, Warmuth M, Friedrich MT, Ehses P, Geistert W, Ritter O, Jakob PM, Ladd ME, Quick HH, Bauer WR: Spatial distribution of RF-induced E-fields and implant heating in MRI. Magn Reson Med 2008, 60(2):312-319.

97. Nordbeck P, Ritter O, Weiss I, Warmuth M, Gensler D, Burkard N, Herold V, Jakob PM, Ertl G, Ladd ME, Quick HH, Bauer WR: Impact of imaging landmark on the risk of MRI-related heating near implanted medical devices like cardiac pacemaker leads. Magn Reson Med 2011, 65(1):44-50.

98. Fontaine JM, Mohamed FB, Gottlieb C, Callans DJ, Marchlinski FE: Rapid ventricular pacing in a pacemaker patient undergoing magnetic resonance imaging. Pacing Clin Electrophysiol 1998, 21(6):1336-1339.

99. Achenbach S, Moshage W, Diem B, Bieberle T, Schibgilla V, Bachmann K: Effects of magnetic resonance imaging on cardiac pacemakers and electrodes. Am Heart J 1997, 134(3):467-473.

100. Buendia F, Sanchez-Gomez JM, Sancho-Tello MJ, Olague J, Osca J, Cano O, Arnau MA, lgual B: Nuclear magnetic resonance imaging in patients with cardiac pacing devices. Rev Esp Cardiol 2010, 63(6):735-739.

101. Yeung CJ, Susil RC, Atalar E: RF heating due to conductive wires during MRI depends on the phase distribution of the transmit field. Magn Reson Med 2002, 48(6):1096-1098.

102. United States Of America Department Of Health And Human Services Food And Drug Administration Center For Devices And Radiological Health Medical Devices Advisory Committee Circulatory System Devices Panel. 2010 [http://www.fda.gov/downloads/ AdvisoryCommittesMeetingMaterials/MedicalDevicesAdvisoryCommittee]

103. Mattei E, Calcagnini G, Censi F, Triventi M, Bartolini P: Numerical model for estimating RF-induced heating on a pacemaker implant during MRI: experimental validation. IEEE Trans Biomed Eng 2010, 57(8):2045-2052.

104. Bottomley PA, Kumar A, Edelstein WA, Allen JM, Karmarkar PV: Designing passive MRI-safe implantable conducting leads with electrodes. Med Phys 2010, 37(7):3828-3843.

105. Hartnell GG, Spence L, Hughes LA, Cohen MC, Saouaf R, Buff B: Safety of MR imaging in patients who have retained metallic materials after cardiac surgery. AJR Am J Roentgenol 1997, 168(5):1157-1159.

106. Kanal E: Safety of MR imaging in patients with retained epicardial pacer wires. AJR Am J Roentgenol 1998, 170(1):213-214.

107. Fries R, Steuer M, Schafers HJ, Bohm M: The R-on-T phenomenon in patients with implantable cardioverter-defibrillators. Am J Cardiol 2003, 91(6):752-755.

108. Chiladakis JA, Karapanos G, Davlouros P, Aggelopoulos G, Alexopoulos D, Manolis AS: Significance of R-on-T phenomenon in early ventricular tachyarrhythmia susceptibility after acute myocardial infarction in the thrombolytic era. Am J Cardiol 2000, 85(3):289-293.

109. Birkholz T, Schmid M, Nimsky C, Schuttler J, Schmitz B: ECG artifacts during intraoperative high-field MRI scanning. J Neurosurg Anesthesiol 2004, 16(4):271-276.

110. Odille F, Pasquier C, Abacherli R, Vuissoz PA, Zientara GP, Felblinger J: Noise cancellation signal processing method and computer system for improved real-time electrocardiogram artifact correction during MRI data acquisition. IEEE Trans Biomed Eng 2007, 54(4):630-640.

111. Kanal E, Barkovich AJ, Bell C, Borgstede JP, Bradley WG Jr, Froelich JW, Gilk T, Gimbel JR, Gosbee J, Kuhni-Kaminski E, Lester JW Jr, Nyenhuis J, Parag Y, Schaefer DJ, Sebek-Scoumis EA, Weinreb J, Zaremba LA, Wilcox P, Lucey L, Sass N: ACR guidance document for safe MR practices: 2007. AJR Am J Roentgenol 2007, 188(6):1447-1474.

112. Levine GN, Gomes AS, Arai AE, Bluemke DA, Flamm SD, Kanal E, Manning WJ, Martin ET, Smith JM, Wilke N, Shellock FS: Safety of magnetic resonance imaging in patients with cardiovascular devices: an American Heart Association scientific statement from the Committee on Diagnostic and Interventional Cardiac Catheterization, Council on Clinical Cardiology, and the Council on Cardiovascular Radiology and Intervention: endorsed by the American College of Cardiology Foundation, the North American Society for Cardiac Imaging, and the Society for Cardiovascular Magnetic Resonance. Circulation 2007, 116(24):2878-2891.

113. Neuzil P, Taborsky M, Rezek Z, Vopalka R, Sediva L, Niederle P, Reddy V: Pacemaker and ICD lead extraction with electrosurgical dissection sheaths and standard transvenous extraction systems: results of a randomized trial. Europace 2007, 9(2):98-104.

114. Neuzner J: Clinical experience with a new cardioverter defibrillator capable of biphasic waveform pulse and enhanced data storage: results 
of a prospective multicenter study. European Ventak P2 Investigator Group. Pacing Clin Electrophysiol 1994, 17(7):1243-1255.

115. Brugada J, Herse B, Sandsted B, Michel U, Schubert BD, Hahn SJ: Clinical evaluation of defibrillation efficacy with a new single-capacitor biphasic waveform in patients undergoing implantation of an implantable cardioverter defibrillator. Europace 2001, 3(4):278-284.

116. Rinaldi CA, Simon RD, Geelen P, Reek S, Baszko A, Kuehl M, Gill JS: A randomized prospective study of single coil versus dual coil defibrillation in patients with ventricular arrhythmias undergoing implantable cardioverter defibrillator therapy. Pacing Clin Electrophysiol 2003, 26(8):1684-1690.

117. Burke PT, Ghanbari H, Alexander PB, Shaw MK, Daccarett M, Machado C: A protocol for patients with cardiovascular implantable devices undergoing magnetic resonance imaging (MRI): should defibrillation threshold testing be performed post-(MRI). I Interv Card Electrophysiol 2010, 28(1):59-66,

118. Shellock FG: Reference Manual for Magnetic Resonance Safety, Implants, and Devices. 2011 edition. Los Angeles: Biomedical Research Publishing Group; 2011.

119. Rezai AR, Finelli D, Nyenhuis JA, Hrdlicka G, Tkach J, Sharan A, Rugieri P, Stypulkowski PH, Shellock FG: Neurostimulation systems for deep brain stimulation: in vitro evaluation of magnetic resonance imaging-related heating at 1.5 tesla. J Magn Reson Imaging 2002, 15(3):241-250.

120. Finelli DA, Rezai AR, Ruggieri PM, Tkach JA, Nyenhuis JA, Hrdlicka G, Sharan A, Gonzalez-Martinez J, Stypulkowski PH, Shellock FG: MR imagingrelated heating of deep brain stimulation electrodes: in vitro study. AJNR Am J Neuroradiol 2002, 23(10):1795-1802.

121. Sharan A, Rezai AR, Nyenhuis JA, Hrdlicka G, Tkach J, Baker K, Turbay M, Rugieri $P$, Phillips M, Shellock FG: MR safety in patients with implanted deep brain stimulation systems (DBS). Acta Neurochir Supp/ 2003, 87:141-145.

122. Rezai AR, Phillips M, Baker KB, Sharan AD, Nyenhuis J, Tkach J, Henderson J, Shellock FG: Neurostimulation system used for deep brain stimulation (DBS): MR safety issues and implications of failing to follow safety recommendations. Invest Radiol 2004, 39(5):300-303.

123. Bhidayasiri R, Bronstein JM, Sinha S, Krahl SE, Ahn S, Behnke EJ, Cohen MS, Frysinger R, Shellock FG: Bilateral neurostimulation systems used for deep brain stimulation: in vitro study of MRI-related heating at $1.5 \mathrm{~T}$ and implications for clinical imaging of the brain. Magn Reson Imaging 2005, 23(4):549-555.

124. Henderson JM, Tkach J, Phillips M, Baker K, Shellock FG, Rezai AR: Permanent neurological deficit related to magnetic resonance imaging in a patient with implanted deep brain stimulation electrodes for Parkinson's disease: case report. Neurosurgery 2005, 57(5):E1063, discussion E1063.

125. Rezai AR, Baker KB, Tkach JA, Phillips M, Hrdlicka G, Sharan AD, Nyenhuis J, Ruggieri $P$, Shellock FG, Henderson J: Is magnetic resonance imaging safe for patients with neurostimulation systems used for deep brain stimulation? Neurosurgery 2005, 57(5):1056-1062, discussion 1056-1062.

126. Ueno S, Yokoyama S, Hirakawa H, Yabe H, Suzuki Y, Atsumi H, Matsumae M: Use of real-time magnetic resonance guidance to assist bone biopsy in pediatric malignancy. Pediatrics 2002, 109(1):E18.

127. Shih MC, Rogers WJ, Hagspiel KD: Real-time magnetic resonance-guided placement of retrievable inferior vena cava filters: comparison with fluoroscopic guidance with use of in vitro and animal models. J Vasc Interv Radiol 2006, 17(2 Pt 1):327-333.

128. Blumenfeld P, Hata N, DiMaio S, Zou K, Haker S, Fichtinger G, Tempany CM: Transperineal prostate biopsy under magnetic resonance image guidance: a needle placement accuracy study. J Magn Reson Imaging 2007, 26(3):688-694.

129. Horvath KA, Li M, Mazilu D, Guttman MA, McVeigh ER: Real-time magnetic resonance imaging guidance for cardiovascular procedures. Semin Thorac Cardiovasc Surg 2007, 19(4):330-335.

130. Nazarian S, Kolandaivelu A, Zviman MM, Meininger GR, Kato R, Susil RC, Roguin A, Dickfeld TL, Ashikaga H, Calkins H, Berger RD, Bluemke DA, Lardo AC, Halperin HR: Feasibility of real-time magnetic resonance imaging for catheter guidance in electrophysiology studies. Circulation 2008, 118(3):223-229.

131. Horvath KA, Mazilu D, Guttman M, Zetts A, Hunt T, Li M: Midterm results of transapical aortic valve replacement via real-time magnetic resonance imaging guidance. J Thorac Cardiovasc Surg 2010, 139(2):424-430.
132. Caviezel A, Terraz S, Schmidlin F, Becker C, Iselin CE: Percutaneous cryoablation of small kidney tumours under magnetic resonance imaging guidance: medium-term follow-up. Scand I Urol Nephrol 2008, 42(5):412-416.

133. Clasen S, Pereira PL: Magnetic resonance guidance for radiofrequency ablation of liver tumors. J Magn Reson Imaging 2008, 27(2):421-433.

134. Hesley GK, Gorny KR, Henrichsen TL, Woodrum DA, Brown DL: A clinical review of focused ultrasound ablation with magnetic resonance guidance: an option for treating uterine fibroids. Ultrasound Q 2008 24(2):131-139.

135. Hatiboglu MA, Weinberg JS, Suki D, Rao G, Prabhu SS, Shah K, Jackson E, Sawaya R: Impact of intraoperative high-field magnetic resonance imaging guidance on glioma surgery: a prospective volumetric analysis. Neurosurgery 2009, 64(6):1073-1081, discussion 1081.

136. Liu ZH, Zhang P, Zhou YK, Qin HL: Percutaneous injection of chemotherapeutic drugs in the guidance of magnetic resonance imaging for the treatment of cholangiocarcinoma. Med Sci Monit 2010, 16(12):HY31-33.

137. Martin AJ, Larson PS, Ostrem JL, Starr PA: Interventional magnetic resonance guidance of deep brain stimulator implantation for Parkinson disease. Top Magn Reson Imaging 2009, 19(4):213-221.

138. Kolb C, Luik A, Hessling G, Zrenner B: Magnetic catheter navigation system interference with a dual-chamber pacemaker. I Cardiovasc Electrophysiol 2007, 18(8):892-893.

139. Neizel M, Kramer N, Bonner F, Schutte A, Kruger S, Kelm M, Gunther RW, Kuhl HP, Krombach GA: Rapid right ventricular pacing with MRcompatible pacemaker lead for MR-guided aortic balloon valvuloplasty in swine. Radiology 2010, 255(3):799-804.

140. Quarta G, Holdright DR, Plant GT, Harkness A, Hausenloy D, Hyare H, Moon JC: Cardiovascular Magnetic Resonance in Cardiac Sarcoidosis with MR Conditional Pacemaker in Situ. J Cardiovasc Magn Reson 2011, 13(1):26.

141. Mitka M: First MRI-safe pacemaker receives conditional approval from FDA. JAMA 2011, 305(10):985-986.

142. Mond HG, Proclemer A: The 11th World Survey of Cardiac Pacing and Implantable Cardioverter-Defibrillators: Calendar Year 2009-A World Society of Arrhythmia's Project. Pacing Clin Electrophysiol 2011, 34(8):1013-1027.

143. Sommer T, Lauck G, Schimpf R, von Smekal A, Wolke S, Block W, Gieseke J, Schneider C, Funke HD, Schild H: MRI in patients with cardiac pacemakers: in vitro and in vivo evaluation at 0.5 tesla. Rofo 1998, 168(1):36-43.

144. Sardanelli F, Lupo P, Esseridou A, Fausto A, Quarenghi M: Dynamic breast magnetic resonance imaging without complications in a patient with dual-chamber demand pacemaker. Acta Radiol 2006, 47(1):24-27.

145. Accent MRI Pacemaker and Tendril MRI Lead New Technology Assesment. [http://clinicaltrials.gov], (NCT01258218).

doi:10.1186/1532-429X-13-63

Cite this article as: Shinbane et al: Magnetic resonance imaging in patients with cardiac pacemakers: era of "MR Conditional" designs. Journal of Cardiovascular Magnetic Resonance 2011 13:63.

\section{Submit your next manuscript to BioMed Central and take full advantage of:}

- Convenient online submission

- Thorough peer review

- No space constraints or color figure charges

- Immediate publication on acceptance

- Inclusion in PubMed, CAS, Scopus and Google Scholar

- Research which is freely available for redistribution 